\title{
A common Ile796Val polymorphism of the human SREBP cleavage-activating protein (SCAP) gene
}

\begin{abstract}
We identified a new common amino acid polymorphism of isoleucine/valine at codon 796 in exon 16 of the gene for human sterol regulatory element binding protein (SREBP) cleavage-activating protein (SCAP), a central regulator of lipid synthesis and metabolism in animal cells. It can be detected as an MslI restriction fragment length polymorphism. The allelic frequencies were: isoleucine (A) allele, 0.57 and valine $(\mathrm{G})$ allele, 0.43 . This polymorphism may be useful for genetic studies of disorders affecting intracellular lipid metabolism and hyperlipidemia.
\end{abstract}

Key words SREBP cleavage-activating protein (SCAP) · Single nucleotide polymorphism (SNP) · Restriction fragment length polymorphism (RFLP) $\cdot$ Lipid metabolism

\section{Introduction}

Sterol regulatory element binding protein (SREBP) cleavage-activating protein (SCAP) is a central regulator of lipid synthesis and uptake in animal cells (Hua et al. 1996; Brown et al. 1997). Point mutations in the sterol-sensing domain of SCAP causes resistance to sterol suppression (Hua et al. 1996; Nohturfft et al. 1998). Mutated cells continue to synthesize cholesterol and to take up low-density lipoprotein (LDL) even when they are massively overloaded with sterols. In transgenic mice that expressed mutant SCAP in liver there was resultant enlargement of the livers, which were engorged with cholesterol and triglycerides (Korn et al. 1998). Given the central role of SCAP in the regulation of lipid metabolism, molecular variants in the human SCAP gene would likely result in alterations in the plasma lipoprotein levels and/or derangement of lipid metabolism within tissues. During screening for disease-associated mutations

K. Iwaki $\cdot$ T. Nakajima $\cdot$ N. Ota $\cdot$ M. Emi $(\bowtie)$

Department of Molecular Biology, Institute of Gerontology, Nippon Medical School, 1-396 Kosugi-cho, Nakahara-ku, Kawasaki 211-8533, Japan

Tel. +81-44-733-5230; Fax +81-44-733-5192

e-mail:memi@nms.ac.jp in hyperlipidemia, we identified a single nucleotide polymorphism in the human SCAP gene. Here we describe an MslI polymorphism for Ile/Val amino acid substitution at codon 796 of the human SCAP gene.

\section{Source and isolation of polymorphisms}

All 23 exons encoding the entire coding sequence of the $S C A P$ gene were screened by polymerase chain reaction (PCR) single-strand conformational polymorphism (SSCP) analysis in 75 Caucasian individuals for nucleotide variations of the gene. PCR-SSCP was carried out following procedures described previously (Hirayama et al. 1998). Variant SSCP bands were identified in the PCR product of exon 16 . These variants were subcloned and sequenced as described by Tsukamoto et al. (1998). Sequence analysis revealed an A-to$\mathrm{G}$ transition at the first nucleotide of codon 796 .

\section{PCR primers}

\section{Forward 5'-TTGTGCTGCGCGGCCACCTCA-3'}

Reverse 5'-AGGAGGAAAGGGCAGCCGCAC-3'

PCR conditions

PCR was performed in a volume of $10 \mu$ l containing $20 \mathrm{ng}$ genomic DNA, $10 \mathrm{mM}$ Tris $\mathrm{HCl}(\mathrm{pH} 8.4), 50 \mathrm{mM} \mathrm{KCl}$, $1.5 \mathrm{mM} \mathrm{MgCl}_{2}, 0.01 \%$ of gelatin, $200 \mu \mathrm{M}$ dNTPs, $2 \mathrm{mCi}$ of [a${ }^{32} \mathrm{P}$ ] dCTP $(3000 \mathrm{Ci} / \mathrm{mmol} ; 10 \mathrm{mCi} / \mathrm{ml}), 2.5 \mathrm{pmol}$ of a forward primer and a reverse primer, and 0.25 units of Taq polymerase. Cycle conditions were $94^{\circ} \mathrm{C}$ for $4 \mathrm{~min}$, then 30 cycles of $94^{\circ} \mathrm{C}$ for $30 \mathrm{~s}, 58^{\circ} \mathrm{C}$ for $30 \mathrm{~s}$, and $72^{\circ} \mathrm{C}$ for $30 \mathrm{~s}$, with a final extension step of $5 \mathrm{~min}$ at $72^{\circ} \mathrm{C}$ in a Gene Amp PCR9600 System (Perkin Elmer Cetus, Norwalk, CT, USA). PCR products were electrophoresed in a $5 \%$ polyacrylamide gel containing $5 \%$ glycerol in $0.5 \times$ Tris-borate-EDTA (TBE) buffer at room temperature. Gels were transferred to filter papers, dried at $80^{\circ} \mathrm{C}$, and autoradiographed. 


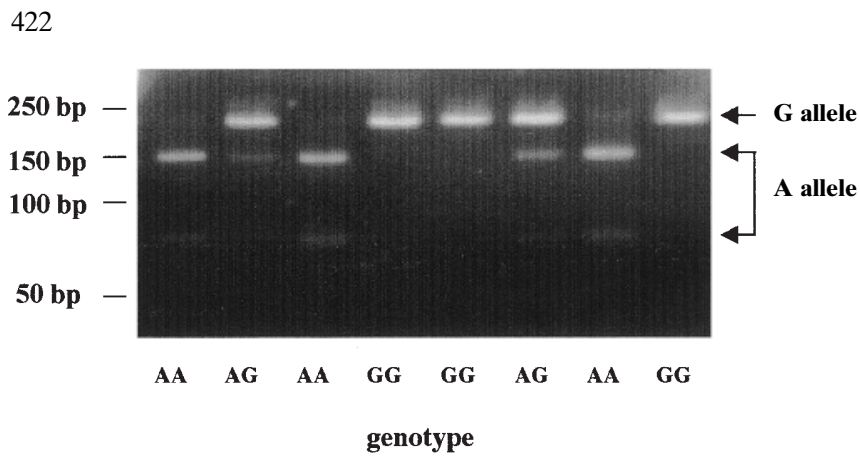

Fig. 1. $M s l \mathrm{I}$ restriction fragment length polymorphism (RFLP) showing an A-to-G substitution at codon 796 in the human SCAP gene. Ms I digestion produced a 235-bp fragment in the $\mathrm{G}$ (Val) allele and 158and 77-bp fragments in the A (Ile) allele

\section{MsI I polymorphism}

An A (Ile)-to-G (Val) transition at the first nucleotide of codon 796 abolishes an $M s l$ I restriction site. Thus, MslI digestion produces a 235-bp fragment in the $\mathrm{G}$ (Val) allele that lacks the $M s l$ I site, while the digestion detects 158 - and 77-bp fragments in the A (Ile) allele having the recognition site, as demonstrated in Fig. 1.

\section{Allele frequency}

The estimated allele frequencies in 150 Caucasian individuals are shown in Table 1 . The observed heterozygosity was 0.49 .

Chromosomal localization. The human SCAP gene was assigned to chromosome band $3 \mathrm{p} 21.3$ by fluorescence in situ hybridization (Nakajima et al. 1999).

Mendelian inheritance. Codominant inheritance was observed in two two-generation families.
Table 1. Estimated allele frequencies of the $S C A P$ gene in 150 caucasian individuals

\begin{tabular}{llcl}
\hline Allele & Amino acid & Msl I fragments & Frequency \\
\hline A allele & Ile & $158+77 \mathrm{bp}$ & 0.57 \\
G allele & Val & $235 \mathrm{bp}$ & 0.43 \\
\hline
\end{tabular}

Other comments. Two rare polymorphisms within the coding sequence of the $S C A P$ gene were also identified during PCR-SSCP screening, as follows; a G-to-A silent substitution at the third nucleotide of codon 1190 in exon 22, and a 5 -bp insertion in the $3^{\prime}$ untranslated region $48 \mathrm{bp}$ downstream from the stop codon in exon 23.

Acknowledgments This work was supported by research grants for primary hyperlipidemia from the Ministry of Health and Welfare of Japan and the Novartis Foundation for Gerontological Research.

\section{References}

Brown MS, Goldstein JL (1997) The SREBP pathway: regulation of cholesterol metabolism by proteolysis of a membrane-bound transcription factor. Cell 89:331-340

Hirayama T, Yamaki E, Hara A, Tsuji M, Hashimoto K, Yamamoto M, Emi M (1998) Five familial hypercholesterolemic kindreds in Japan with novel mutation of the LDL receptor gene. J Hum Genet 43:250-254

Hua X, Nohturfft A, Goldstein JL, Brown MS (1996) Sterol resistance in $\mathrm{CHO}$ cells traced to point mutation in SREBP cleavage-activating protein. Cell 87:415-426

Korn BS, Shimomura I, Bashmakov Y, Hammer RE, Horton JD, Goldstein JL, Brown MS (1998) Blunted feedback suppression of SREBP processing by dietary cholesterol in transgenic mice expressing sterol-resistant SCAP(D443N). J Clin Invest 102:2050-2060

Nakajima T, Hamakubo T, Kodama T, Inazawa J, Emi M (1999) Genomic structure and chromosomal mapping of the human SREBP cleavage-activating protein (SCAP) gene. J Hum Genet 44: (in press)

Nohturfft A, Brown MS, Goldstein JL (1998) Sterols regulate processing of carbohydrate chains of wild-type SREBP cleavage-activating protein (SCAP), but not sterol-resistant mutants Y298C or D443N. Proc Natl Acad Sci USA 95:12848-12853

Tsukamoto K, Haruta K, Shiba T, Emi M (1998) Isolation and mapping of a polymorphic CA repeat sequence at the human interleukin 6 locus. J Hum Genet 43:71-72 